\title{
Helicobacter pylori genotypes identified in gastric biopsy specimens from Jordanian patients
} Laila F Nimri*1, Ismail Matalka², Kamal E Bani-Hani ${ }^{3}$ and Marwa Ibrahim ${ }^{1}$

\author{
Address: ${ }^{1}$ Department of Medical Laboratory Sciences, Jordan University of Science \& Technology, Irbid, Jordan, ${ }^{2}$ Pathology and Microbiology \\ Jordan University of Science \& Technology, Irbid, Jordan and ${ }^{3}$ Surgery, Jordan University of Science \& Technology, Irbid, Jordan \\ Email: Laila F Nimri* - nimri@just.edu.jo; Ismail Matalka - imatalka@hotmail.com; Kamal E Bani-Hani - banihani60@yahoo.com; \\ Marwa Ibrahim - nimri@just.edu.jo \\ * Corresponding author
}

Published: 04 October 2006

BMC Gastroenterology 2006, 6:27 doi:10.1 I86/147|-230X-6-27

This article is available from: http://www.biomedcentral.com/I47I-230X/6/27

(C) 2006 Nimri et al; licensee BioMed Central Ltd.

This is an Open Access article distributed under the terms of the Creative Commons Attribution License (http://creativecommons.org/licenses/by/2.0), which permits unrestricted use, distribution, and reproduction in any medium, provided the original work is properly cited.
Received: II May 2006

Accepted: 04 October 2006

\begin{abstract}
Background: The genetic diversity of Helicobacter pylori can be analyzed at two different levels: the genomic variation between strains originating from different individuals, and the variation in bacterial populations within an individual host. We reported for the first time the $H$. pylori genotypes in Jordanian patients with gastrointestinal diseases.

Methods: Upper endoscopy was performed on 250 patients with symptoms of gastrointestinal diseases. Multiple gastric biopsy specimens were taken from the antrum. All the biopsies were tested by PCR for the $H$. pylori virulence genes vacA, cagA, and iceA, and I5I were tested by histology.

Results: The biopsies positive for $H$. pylori by PCR were I I0/250 (44\%), and by histology I I $7 /$ I5 I (77.5\%), and these results were highly associated $(P<0.02)$. Analyses of virulence genes revealed that iceA2 (73.6\%) was the predominant genotype, the vacAs2 allele was more frequently identified than the vacAs I allele, while the cagA genotype was low (26.4\%). The presence of certain genotypes might be associated with each other, but the presence of certain genotypes was not significantly associated with the age, or gender of the patient.
\end{abstract}

Conclusion: The results illustrate the geographic nature of the genetic diversity of $H$. pylori, as the identified genotypes are similar to those reported in neighboring countries. This study provides a baseline data of $H$. pylori genotypes identified in gastric biopsy specimens from Jordan, serving as a powerful epidemiological tool for prospective investigations to better understand the genetic diversity of this pathogen.

\section{Background}

Helicobacter pylori is a gastric pathogen that chronically infects more than half of all people worldwide. In developing countries, 70-90\% of the population carries $H$. pylori; almost all of these acquire the infection before the age of 10 years [1]. In developed countries, the prevalence is lower, ranging from 25 to $50 \%$ (8) [1], due to the improved socioeconomic conditions over the last few decades [2]. Therefore H. pylori infection in developing countries may contribute to childhood malnutrition and increase the risk or severity of infection by other gastrointestinal pathogens such as Vibrio cholerae [3]. Most infected individuals are asymptomatic or have chronic gastritis $[1,4]$. The differences in disease outcome may be 
the result of a number of factors that include; host factors, environmental factors, and differences in the prevalence or expression of bacterial virulence factors $[4,5]$. The genetic diversity of $H$. pylori can be analyzed at two different levels: the genomic variation between strains originating from different individuals, and the variation in bacterial populations within an individual host [6]. By using randomly amplified polymorphic DNA-PCR and DNA fingerprinting, it has been shown that strains from unrelated infected patients had unique finger prints, whereas strains isolated from family members had very similar although not identical patterns [7]. These results implied that differences observed between strains infecting individual family members occurred after primary infection. Such genetic diversity can be observed among $H$. pylori virulence genes; cagA, vacA, and iceA.

A vacuolating cytotoxin that injures epithelial cells is encoded by vacA gene $[8,9]$, which contains at least two variable parts [10]. The vacAs region (which encodes the signal peptide) exists as $\mathrm{s} 1$ or s2 allelic types, among type $\mathrm{s} 1$ strains, subtypes $\mathrm{s} 1 \mathrm{a}, \mathrm{s} 1 \mathrm{~b}$, and $\mathrm{s} 1 \mathrm{c}$ have been identified [11]. The $\mathrm{m}$ (middle) region occurs as them 1 or the $\mathrm{m} 2$ allelic type, among type $\mathrm{m} 2$, two subtypes have been identified, designated $\mathrm{m} 2 \mathrm{a}$ and $\mathrm{m} 2 \mathrm{~b}$. In general, type $\mathrm{s} 1 \mathrm{~m} 1$ and type $\mathrm{s} 1 \mathrm{~m} 2$ strains produce high and moderate levels of toxin, respectively, while s2 $\mathrm{m} 2$ strains show little or novacuolating toxin activity [10].

The iceA gene, encoding for a putative restriction enzyme, which appears to be induced when $H$. pylori encounters epithelial cells shows allelic variation according to point mutation, resulting in two allelic types, the iceA1 and iceA2 [6]. A study of $H$. pylori infection in patients subjected to an upper gastrointestinal endoscopy in Jordan reported high prevalence [12], and confirmed that its presence was significantly associated with gastritis and peptic ulcer. The current study reports for the first time in Jordan the $H$. pylori genotypes identified in gastric biopsy specimens.

\section{Methods \\ Patients}

A total of 250 consecutive patients who visited King Abdullah Hospital, and Princess Basma Hospital between July 2003 and May 2004, for upper endoscopy were enrolled in the study. These two teaching hospitals are affiliated with Jordan University of Science and Technology, where the study was conducted. Biopsy specimens were taken from the antrum. The study was approved by the Ethics Committee of the University. Each patient signed a written informed consent prior to specimen collection, and all clinical specimens were tested undercode.

\section{Data}

The information provided in the pathology reports or patients' files was recorded for each patient, which included: patient's hospital number, age, gender, history, clinical diagnosis based on histology, endoscopy, and previous treatment (e.g., anti-H. pylori, three had proton pump inhibitors or antacids). The symptoms reported by the patients who underwent upper gastrointestinal endoscopy were abdominal pain, epigastric pain, vomiting, or heartburn.

\section{Histological examinations}

Histological examination was performed on 151 (60.4\%) antral biopsy specimens. Five specimens from the antrum mucosa were taken with medium-sized forceps. Two specimens were embedded in paraffin and the paraffin sections were stained using haematoxylin-eosin and Giemsa methods. The mucosal specimens were evaluated histologically according to the Sydney classification. Coded slides were examined microscopically by a single pathologist using a high power (magnification, $\times 400$ ), and at least five high-power fields were examined.

\section{PCR-based genotyping of three virulence genes}

All the 250 biopsies tested by PCR were stored at $-80^{\circ} \mathrm{C}$ in $70 \%$ ethanol in eppendorf tubes until processed. These biopsies included the 151 biopsies that were tested by histology.

The biopsy specimens were homogenized with a sterile micro pestle, and DNA was extracted using Wizard Genomic DNA purification kit (Promega, Madison, WI, USA), following the manufacturer's instructions for the purification of DNA from animal tissue. The presence of H. pylori was detected by separate PCRs aimed at the cagA, $v a c A \mathrm{~s}$ and $\mathrm{m}$ regions and the ice $A$ genotypes were determined by separate iceA1- and iceA2-specific PCRs as described previously $[13,14]$. Five species-specific primer sets (alpha DNA, Montreal, Canada) were used to amplify highly conserved regions within the indicated genes.

\section{Statistical analysis}

The association between histology and PCR results, and the association between genotypes was analyzed using the Fisher's exact and chi-square tests statistical package for social sciences (SPSS Inc. Chicago, Illinois USA). The difference in mean age between males and females was calculated by independence sample t-test.

\section{Results}

Diagnosis of H. pylori was based on histology, and PCR method. 


\section{Histological findings}

Histological examination of the 151 biopsies revealed that $117(77.5 \%)$ patients were positive for $H$. pylori, therefore were actually infected, and 34 (22.5\%) were negative.

\section{Virulence factors}

The presence of the cagA, vacA s and $m$ regions and the iceA1- and iceA2 genes were investigated in all the 250 biopsies. The biopsies that were PCR positive for one or more of the genes were 110 (44\%), and 140 (56\%) were negative for all genes.

The male: female ratio of the patient population was 58/ 110 (52.7\%) males: 52/110 (47.3\%) females; (mean age $42.03+15.135$ years; range, $17-67$ years $)$.

\section{H. pylori genotypes}

The results of genotyping in 110 biopsies are presented in Table 1.

\section{vacA genotypes}

The sizes of the amplified products for vacA s1 and vacA s2 are 259 bp and 286 bp respectively. The intensities of the products varied between specimens. The vacA s region was amplified in 75/110 (68.2\%) biopsies. The s1 variant was detected in $34 / 75$ (45.3\%), or 34/110 (30.9\%), compared to the s 2 variant, which was detected in $41 / 75$ (54.7\%), or $41 / 110(37.3 \%)$ of the biopsies. The vacA m region was detected in $47 / 110(42.7 \%)$ biopsies. The $\mathrm{m} 1$ variant was detected in 23/47 (48.9\%) or 23/110 (20.9\%), compared to $\mathrm{m} 2$ variant detected in $24 / 47(51 \%)$, or $24 / 110$ $(21.8 \%)$.

A combination of the vacA $\mathrm{s}$, and $\mathrm{m}$ regions was detected in $26 / 110(23.6 \%)$ of the biopsies. Both vacA $\mathrm{s} 1 \mathrm{~m} 1$ and vacA $\mathrm{s} 2 \mathrm{~m} 2$ were detected in approximately equal amounts in $12 / 26(46.2 \%)$, of the vacA sm genotype, or $12 / 110$ $(10.9 \%)$, whereas vacA $\mathrm{s} 1 \mathrm{~m} 2$ was detected in only $2 / 26$

Table I: Prevalence of Helicobacter pylori genotypes detected in II 0 biopsies

\begin{tabular}{|c|c|}
\hline Genotype & Prevalence (\%) \\
\hline vacAs I & $34(45.3)$ \\
\hline vacAs2 & $4 I(54.7)$ \\
\hline vacAm I & $23(48.9)$ \\
\hline vacAm2 & 24 (5I.I) \\
\hline vacAs Im I & $12(46.2)$ \\
\hline $\operatorname{vac} A s 2 \mathrm{~m} 2$ & $12(46.2)$ \\
\hline $\operatorname{vac} A s \operatorname{lm} 2$ & $2(7.7)$ \\
\hline vacAs $2 \mathrm{ml}$ & $0(0.0)$ \\
\hline $\operatorname{cag} A$ & $29(26.4)$ \\
\hline iceAl & $0(0.0)$ \\
\hline iceA2 & $81(73.6)$ \\
\hline
\end{tabular}

$(7.7 \%)$ of the vacA sm genotype, or $2 / 110$ (1.8\%). None of the biopsies showed the vacA $\mathrm{s} 2 \mathrm{~m} 1$ genotype, or multiple genotypes.

\section{cagA genotype}

The size of the $\operatorname{cag} A$ amplified product was $349 \mathrm{bp}$. The cagA genotype was detected in 29/110 (26.4\%), and 81 $(73.6 \%)$ were negative.

\section{The association between the cagA and vacAs I genotypes}

The cagA genotype was detected in $8 / 17$ (47.1\%) of the vacA s1 genotype, compared to only $2 / 20(10 \%)$ of the vacA s2 genotype.

\section{iceA genotype}

None of the 110 biopsies showed the iceA1 genotype, while 81 (73.6\%) showed the iceA2 genotype. The iceA2 amplification yielded both the 229 bp and 334 bp fragments, this difference in the fragment size is due to the presence of a $105 \mathrm{bp}$ in - frame amplicon present in the $334 \mathrm{bp}$ fragment that is absent in the 229 bp fragment [15].

The association between the genotypes and gender

Although certain genotypes were detected more in one sex than the other, their presence was not significantly associated with the age, or gender of the patient. The genotypes that were detected more in males than females were the vacA s1 9/17 (53\%), cagA 16/29 (55.2\%), iceA2 45/81 (55.5\%), vacA s $1 \mathrm{~m} 17 / 12(58.3 \%)$, and the combined vacA s1 cagA genotypes $6 / 8$ (75\%). The genotypes that were detected more in females were the vacA s2 $11 / 19$ (65\%), vacA m2 15/20 (75\%), vacA s $2 \mathrm{~m} 2$ 8/11 (72.7\%), and the combined vacA s2 cagA genotypes $2 / 2$ (100\%). The vacA $\mathrm{m} 1$, and $v a c A \mathrm{~s} 1 \mathrm{~m} 2$ genotypes were detected in approximately equal amount in both sexes.

\section{Statistical analysis}

The overall positive PCR results were highly associated $(P$ $<0.02$ ) with histology results. Analysis of data showed a significant association between the simultaneous detection of both $\operatorname{cag} A$ and vacAs 1 genotypes $(P=0.026)$, the combination of both the vacAs 1 and the vacAm 1 genotypes $(P<0.0001)$, and the combination of both the vacAs 2 and the vacAm 2 genotypes $(P<0.0001)$. On the other hand, no association was observed between the detection of both the vacAs 2 and $\operatorname{cag} A$ genotypes $(P=$ $0.102)$, the detection of more than one genotype with either age or gender $(P>0.05)$, the combination of both the vacAs 1 and the vacAm 2 genotypes $(P>0.05)$, and the combination of both the vacAs 2 and the vacAm 1 genotypes $(P>0.05)$. 


\section{Discussion}

The present study reports on the vacA, cagA, and iceA genotypes of $H$. pylori that were identified in gastric biopsies. Although all strains carry a copy of the vacA gene, with either the s1 or s2 signal sequences, the vacA s region was amplified in 75/110 (68.2\%) biopsies. Similar results were reported by other studies indicating that additional subfamilies of $\mathrm{s}$ and $\mathrm{m}$ genotypes beside the known ones may exist [16].

The predominant genotype in the 110 biopsies that were positive for $H$. pylori by PCR, was the iceA2 (73.6\%), followed by the vacAs genotype $(68.2 \%) ; 34(45.3 \%)$ of these were the vacA s1 allele, and 41 (54.7\%) were the $v a c A$ s2 allele, while the cagA genotype was amplified only in $29 / 110(26.4 \%)$ of the biopsies. Our results are in agreement with other studies conducted on Israeli children [13], and Egyptian patients [15], where the cagA genotype was reported in $28 \%$, and $36 \%$ respectively. The similarity of the genotypes identified in the three studies could be explained by a primary geographic influence important in the adaptation of the organism to the environment and climatic conditions [13], despite the obvious host differences in life style in two neighboring countries. The close resemblance of strains in neighboring countries was also reported in Bangladesh and Calcutta, India $[3,17]$, which is quite likely considering the close proximity of the two countries, the similar physiological environments, and life styles of the host.

Higher prevalence ( $67 \%$ or more) of the cagA genotype in H. pylori was reported in Europe, Central and South America, and East Asia [15]. The vacA s2 allele was detected in less than $30 \%$ in the studied population in most of these countries. Prevalence rates of this genotype similar to the current study (54.7\%) were reported in Egypt (50\%) [15], while higher rates (65\%) were reported in the Israeli study [11]. A study in Kuwait reported that vacA s1 and s2 types were detected in approximately equal numbers in biopsies obtained from patients of Middle-Eastern origin, while African Arabs were predominantly infected with the s2 type [18]. A study of genotypes in four different countries reported that the $c a g A$, and $v a c A \mathrm{~s} 1 \mathrm{ml}$ ice $A 1$ genotypes were predominant in both Japan and Korea [14], and the cagA, vacA s $1 \mathrm{~m} 1$, iceA2 genotypes were frequently identified in the United States, while the cagA, vacA s $1 \mathrm{~m} 1$, iceA2 genotypes were predominant in Colombia. The same study reported higher prevalence of the vacA $\mathrm{s} 1$ than the vacA s2 genotype, and a high prevalence of the cagA genotype; however, the prevalence of the iceA1 and iceA2 genotypes varied among these countries. A study conducted in England reported that the vacA s $1 \mathrm{~m} 1$ genotype was found to be less common in England [19], while a predominance of iceA1 alleles, cagA, and the presence of vacA $\mathrm{m} 1$ alleles were observed. Turkish strains examined predominantly possessed the cagA, vacA s $1 \mathrm{~m} 1$, or $v a c A \mathrm{~m} 2$ genotypes, which were the typical genotypes in strains from Western countries [20]. The predominance of the vacA sl/m1 allelic combination, and a high prevalence of the cagA gene $(87 \%)$ were also reported in Estonia $H$. pylori strains [21].

Based on the presence of a combination of the vacAs, and $\mathrm{m}$ alleles, the vacA s1 allele was significantly associated with vacA $\mathrm{m} 1(P<0.0001)$, and the same association was observed between the vacA s2 and the vacA $\mathrm{m} 2(P<$ $0.0001)$ alleles. However, the detection of both vacA s1 and vacA $\mathrm{m} 2$ alleles was independent of each other $(P>$ $0.05)$. The vacA s $1 \mathrm{~m} 2$ genotype was detected only in $2 / 26$ $(7.7 \%)$ of the vacA sm combination. In addition, there was no significant association between the vacA s2 and vacA $\mathrm{m} 1$, meaning that the detection of each allele was independent of the other $(P>0.05)$. This finding may explain the absence of the combined $\mathrm{s} 2 / \mathrm{m} 1$ genotype from the isolates in the study that was reported previously $[22,23]$. However, the first case of vacA s $2 \mathrm{~m} 1 \mathrm{H}$. pylori isolate was reported in a duodenal ulcer patient from South Africa [24].

The significant association between the vacA s1 allele and cagA genotype (47.1\%) in our study was also reported in $50 \%$ of the Israeli and Egyptian isolates $[13,14]$. An association of more than $85 \%$ of the isolates was reported in other countries $[15,22]$, confirming that the two markers are closely related. Our study showed no significant association in the detection of two genotypes in the same isolate such as the $\operatorname{cag} A$ with the iceA2, the vacA $\mathrm{m} 2$ allele with the iceA2 genotype, and the vacA s $2, \mathrm{~m} 2$ alleles with the iceA2 indicating that the detection of one gene was independent of the other. Moreover, the detection of the combined vacA s1 m1, and iceA2 genotypes in few biopsies was insignificant $(P>0.05)$, indicating that the detection of iceA2 was independent of the vacA genotypes. The same findings were reported by a previous study [22]. None of the strains had multiple vacA genotypes, which were reported in other countries such as northern South America [15].

Females were more often carrying the vacA s2, and the vacA $\mathrm{m} 2$ genotypes (65\%, and $75 \%$, respectively) compared to $(42 \%$, and $25 \%)$ in males. The iceA2 (55.5\%), cagA (55.2\%), and vacA s1 (53\%) genotypes were detected more in males than females. The gender of the patient and the detection of certain genotypes or combination of genotypes were not significantly associated. Moreover, the $H$. pylori genotypes $(P>0.05)$, and the detection of more than one genotype had no significant association with either age or gender of the patient. 
The overall positive PCR results were highly associated $(P$ $<0.02$ ) with histology results. The differences in the histology, and PCR results could be due to the patchy distribution of the $H$. pylori in the stomach. Moreover, false negatives might be a problem in genotyping from biopsies since some biopsies were found to contain compounds inhibiting the PCR [25]. In addition, testing more multiple biopsies by histology compared to one by PCR increased the possibility of finding the bacterium, and explains the more positive results obtained by histology (77.5\%), compared to PCR $(44 \%)$. The treatments of patients with the proton pump inhibitors, antacids, or anti-H. pylori therapy may have lead to the negative results in the tests performed in these patients [26].

\section{Conclusion}

Jordanian strains examined predominantly possessed the iceA2 allele, the vacAs2 allele was detected more than the vacA s1 allele, while the cagA genotype was low. The detection of certain genotypes might be associated with each other. The results illustrate the geographic nature of the genetic diversity of $H$. pylori, as the identified genotypes are similar to those reported in neighboring countries.

This study provides a baseline framework of $H$. pylori genotypes identified in gastric biopsy specimens, serving as a powerful epidemiological tool for prospective investigations to better understand the genetic diversity of this pathogen.

\section{Competing interests}

The author(s) declare that they have no competing interests.

\section{Authors' contributions}

All authors read and approved the final manuscript.

LN designed and coordinated the study, optimized PCR conditions, carried out molecular analysis and wrote the manuscript. IM performed histological examination, and interpretation of results. KBH recruited patients, carried out endoscopies and gastric biopsies. MF performed the PCR, participated in the data analysis.

\section{Acknowledgements}

The authors thank the gastroenterologists and nurses in the Department of Endoscopy at King Abdullah and Princess Basma hospitals, who helped in the specimen collection. The study was supported by grant \# I5/04 from the Deanship of Research at Jordan University of Science \& Technology.

\section{References}

I. Dunn BE, Cohen H, Blaser MJ: Helicobacter pylori. Clin Microbiol Rev 1997, 10:720-741.

2. Taylor DN, Parsonnet J: Epidemiology and natural history of $\boldsymbol{H}$. pylori infections. In Infections of the gastrointestinal tract Edited by: Blaser MJ, Smith PF, Ravdin J, Greenberg H, Guerrant RL. New York, Raven Press; 1995:55I-564.
3. Mukhopadhyay AK, Kersulyte D, Jeong JY, Datta S, Ito Y, Chowdhury A, Chowdhury S, Santra A, Bhattacharya SK, Azuma T, Nair GB, Berg $\mathrm{DE}$ : Distinctiveness of Genotypes of Helicobacter pylori in Calcutta. India Jacteriol 2000, I 82:3219-3227.

4. Bani-Hani KE: The current status of Helicobacter pylori. Saudi Med J 2002, 23:279-283.

5. Tomb JF, White O, Kerlevage AR, the Helicobacter Genome Sequencing Group: The complete genome sequence of the gastric pathogen Helicobacter pylori. Nature 1997, 388:539-547.

6. Marais A, Mendz GL, Hazell SL, Megraud F: Metabolism and genetics of Helicobacter pylori: the genome era. Microbiol Mol Biol Rev 1999, 63:642-674.

7. van der Ende A, Rauws EA, Feller M, Mulder JC, Tytagat JG, Dankert J: Heterogeneous Helicobacter pylori isolates from members of family with history of peptic ulcer disease. Gastroenterol 1996, I I I:638-647.

8. Cover TL: The vacuolating cytotoxin of Helicobacter pylori. Mol Microbiol 1996, 20:24I-246.

9. Telford JL, Ghiara P, Dell'Orco M, Comanducci M, Burroni D, Bugnoli M, Tecce MF, Censini S, Covacci A, Xiang Z: Gene structure of the Helicobacter pylori cytotoxin and evidence of its key role in gastric disease. J Exp Med 1994, 179:1653-1658.

10. Atherton JC, Cao P, Peek RM, Tummuru MK, Blaser MJ, Cover TL: Mosaicism in vacuolating cytotoxin alleles of Helicobacter pylori. Association of specific vacA types with cytotoxin production and peptic ulceration. I Biol Chem 1995, 270: 1777।-17777.

II. van Doorn LJ, Figueiredo C, Sanna R, Pena S, Midolo P, Ng EK, Atherton JC, Blaser MJ, Quint WG: Expanding allelic diversity of Helicobacter pylori vacA. J Clin Microbiol 1998, 36:2597-2603.

12. Bani-Hani KE, Hammouri SM: Prevalence of Helicobacter pylori in northern Jordan: Endoscopy based study. Saudi Med J 200I, 22:837-843.

13. Benenson S, Halle D, Rudensky B, Faber J, Schlesinger Y, Branski D, Rabinowtiz N, Wilschanski M: Helicobacter pylori genotypes in Israeli children: The significance of geography. J Pediatr Gastroenterol Nutr 2002, 35:680-684.

14. Yamaoka Y, Kodama T, Gutierrez O, Kim JG, Kashima K, Graham DY: Relationship between Helicobacter pylori iceA, cagA, and vacA status and clinical outcome: studies in four different countries. J Clin Microbiol 1999, 37:2274-2279.

15. van Doorn LJ, Figueiredo C, Megraud F, Pena S, Midolo P, Queiroz DM, Carneiro F, Vanderborght B, Pegado MD, Sanna R: Geographic distribution of vacA allelic types of Helicobacter pylori. Gastroenterol 1999, I 16:823-830.

16. Garza-Gonzalez E, Bosques-Padilla FJ, Tijerina-Menchaca R, PerezPerez Gl: Characterisation of Helicobacter pylori isolates from the north-eastern region of Mexico. Clin Microbiol Infect 2004, I0:4I-45.

17. Rahman M, Mukhopadhyay AK, Nahar S, Datta S, Ahmad MM, Sarker S: DNA-level characterization of Helicobacter pylori strains from patients with overt disease with benign infections in Bangladesh. J Clin Microbiol 2003, 4I:2008-20I4.

18. Al Qabandi A, Mustafa AS, Siddique I, Khajah AK, Madda JP: Distribution of vacA and cagA genotypes of Helicobacter pylori in Kuwait. Acta Trop 2005, 93:283-288.

19. Kauser F, Hussain MMA, Ahmed I, Srinivas S, Devi SM, Majeed AA, Rao KR, Khan AA, Sechi LA, Ahmed N: Comparative genomics of Helicobacter pylori isolates recovered from ulcer disease patients in England. BMC Microbiol 2005, 5:32.

20. Saribasak H, Salih BA, Yamaoka Y, Sander E: Analysis of Helicobacter pylori genotypes and correlation with clinical outcome in Turkey. J Clin Microbiol 2004, 42: 1648-5I.

2I. Anderson H, Loivukene K, Sillakivi T, Maaroos HI, Ustav M, Peetsalu'A Mikelsaar M: Association of cagA and vacA genotypes of Helicobacter pylori with gastric disease in Estonia. J Clin Microbiol 2002, 40:298-300.

22. Rudi J, Kolb C, Maiwald M, Kuck D, Sieg A, Galle PR, Stremmel W: Diversity of Helicobacter pylori vacA and cagA genes and relationship to VacA and CagA protein expression, cytotoxin production, and associated disease. J Clin Microbiol 1998, 36:944-948.

23. Rota CA, Pereira-Lima JC, Blaya C, Nardi NB: Consensus and variable region PCR analysis of Helicobacter pylori 3' region of cagA gene in isolates from individuals with or without peptic ulcer. J Clin Microbiol 200I, 39:606-6I2. 
24. Kidd M, Lastovica AJ, Atherton JC, Louw JA: Heterogeneity in the Helicobacter pylori vacA and cagA genes: Association with gastroduodenal disease in South Africa? Gut 1999, 45:499-502.

25. Thoreson AC, Borre M, Andersen LP, Jorgensen F, Kiilerich S, Scheibel J, Rath J, Krogfelt KA: Helicobacter pylori detection in human biopsies: a competitive PCR assay with internal control reveals false results. FEMS Immunol Med Microbiol 1999, 24:20I-208.

26. van Doorn LJ, Henskens $Y$, Nouhan N, Verschuuren A, Vreede R, Herbink P, Ponjee G, van Krimpen K, Blankenburg R, Scherpenisse J, Quint W: The efficacy of laboratory diagnosis of Helicobacter pylori infections in gastric biopsy specimens is related to bacterial density and vacA, cagA, and iceA genotypes. J Clin Microbiol 2000, 38:13-17.

\section{Pre-publication history}

The pre-publication history for this paper can be accessed here:

http://www.biomedcentral.com/1471-230X/6/27/pre

pub

Publish with Bio Med Central and every scientist can read your work free of charge

"BioMed Central will be the most significant development for disseminating the results of biomedical research in our lifetime. "

Sir Paul Nurse, Cancer Research UK

Your research papers will be:

- available free of charge to the entire biomedical community

- peer reviewed and published immediately upon acceptance

- cited in PubMed and archived on PubMed Central

- yours - you keep the copyright

Submit your manuscript here:

http://www.biomedcentral.com/info/publishing_adv.asp 